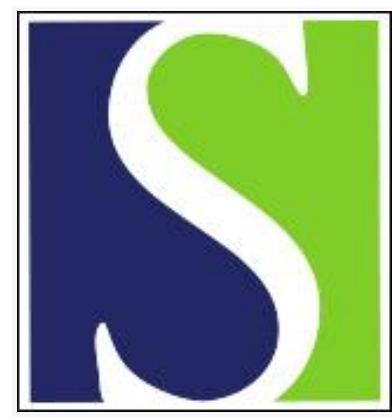

Scand J Work Environ Health 2018;44(5):443-457

https://doi.org/10.5271/sjweh.3731

Published online: 30 Apr 2018, Issue date: 01 Sep 2018

Content and quality of workplace guidelines developed to prevent mental health problems: results from a systematic review

by Nexø MA, Kristensen JV, Grønvad MT, Kristiansen J, Poulsen OM

To date, no study has systematically reviewed guidelines that aim to help workplaces prevent or detect work-related mental health problems early. The evidence underpining most of workplace guidelines is scarce. Greater transparency of the incentives driving guideline development and improvement of theoretical and scientific rigor of implementation frameworks can improve content and developmental quality of future workplace guideline development.

Affiliation: Steno Diabetes Center Copenhagen Health Promotion, Niels Steensens Vej 6, 2820 Gentofte, Denmark. mette.andersen.nexoe@regionh.dk

The following articles refer to this text: 2018;44(5):441-442;

2022;48(3):173-189

Key terms: depression; mental health problem; review; sick-leave; systematic review; work disability; workplace guideline; workplace intervention

This article in PubMed: www.ncbi.nlm.nih.gov/pubmed/29717327

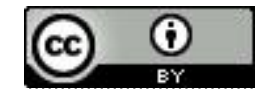




\title{
Content and quality of workplace guidelines developed to prevent mental health problems: results from a systematic review
}

\author{
by Mette Andersen Nexø, PhD, ${ }^{1}$ Josefine Vejlby Kristensen, MA, ${ }^{2}$ Majbritt Thorhauge Grønvad, MA, ${ }^{2}$ Jesper Kristiansen, PhD, ${ }^{2}$ \\ Otto Melchior Poulsen, PhD²
}

\begin{abstract}
Nexø MA, Kristensen JV, Grønvad MT, Kristiansen J, Poulsen OM. Content and quality of workplace guidelines developed to prevent mental health problems. Results from a systematic review. Scand J Work Environ Health. 2018;44(5):443-457. doi:10.5271/sjweh.3731
\end{abstract}

Objectives A wide range of guidelines have been developed to prevent work-related mental health problems (MHP), but little is known about the quality of such guidelines. We systematically reviewed the content and quality of workplace guidelines aiming to prevent, detect, and/or manage work-related MHP.

Methods We conducted systematic online and database searches (MEDLINE; Web of Science; PsychNET; occupational safety and health databases) to identify guidelines. Eligibility criteria included guidelines recommending primary, secondary, or tertiary preventive interventions to be implemented at the workplace by employers, employees or organizational staff. A minimum of minimum three independent reviewers assessed the quality of guidelines using the Guidelines for Research and Evaluation (AGREE II). Guidelines rated $\geq 65 \%$ with regards to domain I, II, and III were considered to be of good developmental quality.

Results Seventeen guidelines were quality assessed. Guidelines mainly targeted employers: eight guidelines recommended primary preventive interventions (eg, reduction of psychosocial hazards by risk management procedures), three recommended tertiary (eg, stay at work or return to work procedures for management), and six recommended a combination of primary, secondary and tertiary interventions (eg, facilitate return to work by increasing mental health literacy of all staff and coordination of sick-listed employees). Four guidelines had developed recommendations of good quality, but the evidence of two guidelines was outdated and studies documenting the effect of implementation were not yet available.

Conclusions Few guidelines have been developed with sufficient rigor to help employers prevent or manage work-related MHP and evidence of their effectiveness remains scarce.

Key terms depression; sick-leave; work disability; workplace intervention.

Mental health problems (MHP) severely challenge work force productivity (1). Anxiety, depression and stressrelated disorders are common and the leading causes of work disability and early retirement in most Western countries (2-5). The workplace plays an essential role in relieving the burden of disability due to MHP (6). Therefore several international organizations have called for new policies, regulations and accompanying guidelines to help prevent work-related MHP $(7,8)$.

Guidelines providing evidence-based recommendations may enable workplaces to prevent work-related MHP in at least four ways. Primary preventive interventions aim to prevent MHP before they develop, by either reducing or eliminating exposure to occupational risks (9) or promoting positive factors that make the organization, teams or the individual employee more resilient to workplace stressors $(10,11)$. Secondary preventive interventions target individuals at risk of developing MHP. The workplace can intervene early when an employee exhibits signs of MHP, which may relieve symptoms and prevent unnecessary sickness absence (12). Tertiary preventive interventions aim to manage and rehabilitate workers with MHP, who need sick-leave due to MHP. Workplace interventions facilitating employees return to work (RTW) may accelerate recovery and prevent prolonged or recurrent sick-leave

1 Steno Diabetes Center Copenhagen Health Promotion, Gentofte, Denmark.

2 The National Research Center for the Working Environment, Copenhagen, Denmark.

Correspondence to: Mette Andersen Nexø, PhD, Steno Diabetes Center Copenhagen Health Promotion, Niels Steensens Vej 6, 2820 Gentofte, Denmark. [E-mail: mette.andersen.nexoe@regionh.dk] 
(13). Finally, recent theoretical developments suggest that to achieve the desired work- and health-related outcomes a combination of primary along with secondary or tertiary preventive interventions is necessary to achieve the desired effects (14).

Workplace interventions involve multiple disciplines and the effect depends on the complex interplay between organizational, environmental and individual factors (15). Although the effects are highly context-dependent, a few workplace interventions have been identified in the research literature to effectively relieve or manage work-related stress (16). Guidelines can in this regard be useful instruments that convert the best available evidence into practical advice that assist employers in best practice.

The extent to which the statements in the guideline are adequately developed (eg, evidence-based) help determine whether the guideline is effective in achieving the desired occupational health outcomes (17). Although a wide range of guidelines have been developed in recent years (7), little attention has been paid to their quality.

To our knowledge, no study has yet evaluated the quality of guidelines that aim to guide employers in how to prevent work-related MHP. However, one review has systematically assessed the quality of guidelines involving multiple levels of prevention with regards to their comprehensiveness (18). They concluded that the developmental process of guidelines lacked rigor and mostly focused on individual as opposed to organizational means of prevention. Two reviews systematically assessed guidelines that facilitated RTW $(19,20)$. Joosen et al (19) only evaluated guidelines developed for occupational physicians and the results are therefore not applicable to interventions that can be implemented by employers. Dewa et al (20) evaluated the developmental quality of three best practice guidelines. All reviews concluded that the content of guidelines was complementary, but few met minimum standards for development and reporting quality. Since only best practice guidelines published until 2014 were eligible for inclusion, a new review is needed to enable updated information on the quality of available guidelines and identify needs for improvement.

This study aimed to: (i) systematically review the developmental quality of guidelines providing recommendations for actors at the workplace (top and first line managers, organizational staff such as HR personnel, colleagues) to prevent work related MHP, detect and manage early signs of MHP in employees, or facilitate return to work; and (ii) compare the content of recommended interventions included in guidelines and the reported evidence underpinning the expected outcomes of interventions.

\section{Methods}

This study was a systematic review following the general principles of PRISMA (21). The review was carried out at the National Research Centre for the Working Environment (NRCWE) from January to August 2016.

\section{Systematic literature search}

Since conventional database searches have previously shown to be ineffective in identifying occupational health guidelines (19), we conducted a systematic search of the grey literature in addition to a systematic database search.

\section{Grey literature search}

Two scientific assistants performed a general Google search along with a selective web search between May and July 2016.

General Google search. We searched for guidelines in English with English keywords via google.com (workplace, work, occupational, mental health, wellbeing, stress, psychological, depression, anxiety, common mental disorders, national, standard, guidelines, return to work). These keywords were combined into 24 different search strings. For each search string, the first 50 hits were examined. Only unique references were registered in each search. The primary searches often suggested links to alternative websites and, if relevant, these were further examined. We also searched specifically for guidelines in Danish, Swedish and Norwegian, using Danish, Swedish and Norwegian keywords for searches at google.dk, google.se and google.no.

Selective web search. We searched for guidelines on the websites of selected occupational health and safety organizations in the Partnership of European Research Institutions on Occupational Safety and Health (PEROSH), websites of international organizations focusing on mental health and work (eg, the International Labor Organization, the European Network for Workplace Health Promotion, the World Health Organization, OECD, the EU, the US (eg, NIOSH), Canada (eg, CCOHS) and Australia (eg, Beyond Blue).

\section{Database search}

A librarian at the NRCWE undertook a systematic literature search. The search string was defined by our inclusion/exclusion criteria (table 1) and adapted to the interfaces of five database sources: (i) Medline via the PubMed interface: www.ncbi.nlm.nih. 
Table 1. Inclusion and exclusion criteria of guidelines in accordance with PIPOH (population, intervention, professionals, outcome, health setting).

\begin{tabular}{|c|c|c|}
\hline & Inclusion criteria & Exclusion criteria \\
\hline $\begin{array}{l}\text { Population: } \\
\text { Populations targeted } \\
\text { in the recommended } \\
\text { interventions }\end{array}$ & $\begin{array}{l}\text { Guidelines recommending workplace interventions for employed individuals (eg, the indi- } \\
\text { vidual employee, specific employee groups/teams, or all employees or employee groups with } \\
\text { specific functions such as teams at high risk of psychosocial hazards or management). }\end{array}$ & $\begin{array}{l}\text { Guidelines recommending interventions } \\
\text { targeting unemployed individuals }\end{array}$ \\
\hline Intervention & $\begin{array}{l}\text { Guidelines recommending interventions that can be implemented at the workplace. They can } \\
\text { be at the organizational level (eg, policies, strategic and action based procedures, educa- } \\
\text { tional programs, psychosocial hazards, peer support) group or individual level (eg, training to } \\
\text { increase individual health, coping or work competences that influence } \mathrm{MH} \text { ) }\end{array}$ & $\begin{array}{l}\text { Guidelines recommending interventions } \\
\text { outside the workplace (eg, treatment of } \\
\text { mental disorders) }\end{array}$ \\
\hline $\begin{array}{l}\text { Professionals: } \\
\text { Individuals responsible } \\
\text { for implementing } \\
\text { the guideline }\end{array}$ & $\begin{array}{l}\text { Guidelines recommending interventions that can be implemented by actors at the workplace } \\
\text { (eg, employers, top-management, first line managers, colleagues) or appointed people within } \\
\text { the organizations (eg, Human Resource representatives, health and safety representatives, } \\
\text { union representatives, employees) }\end{array}$ & $\begin{array}{l}\text { Interventions developed for professionals } \\
\text { outside the workplace, eg, occupational } \\
\text { health professionals, psychiatrists }\end{array}$ \\
\hline Outcomes & $\begin{array}{l}\text { Guidelines recommending interventions that aim to promote MH or prevent MHP (eg, pre- } \\
\text { venting incidence of work related MHP) or associated disability and work related outcomes } \\
\text { (eg, organizational excellence, management competences, productivity, sickness absence, } \\
\text { retention) }\end{array}$ & Outcomes that only entail work outcomes \\
\hline Health setting ${ }^{a}$ & Guidelines targeting the workplace (Occupational health) & $\begin{array}{l}\text { Guidelines outside workplace settings, } \\
\text { eg, healthcare or social services }\end{array}$ \\
\hline
\end{tabular}

${ }^{\mathrm{a}}$ Healthcare setting reframed to health setting.

gov/pubmed;PsycNET via the APA host interface: psycnet.apa.org; (iii) Web of Science includes the three databases Science Citation Index Expanded (SCIEXPANDED), Social Sciences Citation Index (SSCI) \& Arts \& Humanities Citation Index (A\&HCI) and was searched via the host interface: apps.webofknowledge.com; (iv) OSH UPDATE includes the databases CISDOC, HSELINE, NIOSHTIC, RILOSH and was searched via the host interface: www.oshupdate.com; and (v) National Guideline Clearinghouse (NGC) is a public resource for summaries of evidence-based clinical practice guidelines maintained by the American Agency for Healthcare Research and Quality. The NGC was searched via the interface: www.guideline.gov.

The database search included articles published until 14 July 2016. Articles were also identified by screening the reference lists of relevant single studies and reviews for potential pertinent titles.

\section{Consultation with experts}

We consulted colleagues/experts in the field for relevant guidelines to be included in the review.

\section{Eligibility criteria}

Inclusion and exclusion criteria were developed in accordance with PIPOH (population, intervention, professional, outcomes, health setting) (22) (table 1). To be included, guidelines had to be written in English, Danish, Swedish, or Norwegian and published after 1999. The guidelines had to fulfil the definition of a guideline (23) and be systematically developed based on best available evidence or best practice. The guidelines had to recommend interventions that could be implemented by actors at the workplace (eg, employers, employees or organizational staff such as human resource personnel). Interventions at the organizational level (eg, organizational procedures, work conditions) or at the individual level (eg, competence training, stress management) had to target employed individuals. The interventions should prevent work-related MHP or improve mental health and work-related outcomes. We excluded guidelines recommending interventions outside the workplace or required implementation by professionals outside or in the periphery of the workplace. The criteria were pilot tested on ten selected documents.

\section{Selection of guidelines (procedure)}

Two research assistants and two researchers with 2-26 years of research experience carried out the review procedure.

Review procedure of documents retrieved from the grey literature. The two research assistants screened and compared the fulltext of those documents that were identified as guidelines published after 1999 for eligibility. A nonblinded second researcher assessed the eligible documents.

Review procedure of documents retrieved from the database search. One researcher performed the title/abstract and fulltext screening for potential eligibility of journal articles from the database search. The researcher first screened for eligibility by title/abstract and then fulltext. A research assistant then screened the selected articles for eligibility.

\section{Data extraction and comparison of guidelines}

For each eligible guideline, we extracted information about the type of publication; the methods applied to 
develop evidence based recommendations (eg, systematic review); methods to involve stakeholders (eg, Delphi study); the type of guideline; the population responsible for implementing the guideline (eg, employers); and the target population (s) intended for the interventions (eg, employees). Since the effects of implementing guidelines have not yet been evaluated, we were unable to extract the effects sizes of guidelines for comparison. However, we extracted the reported main outcomes expected by implementing the interventions. We also extracted the content of those recommendations that could be characterized as interventions. Interventions were defined as formalized activities, programs, procedures or processes at the individual level (eg, training to improve individual competences) or organizational level (eg, formalized procedures, processes to eliminate psychosocial hazards). The characteristics of guidelines and interventions were outlined and compared.

\section{Quality assessment}

The quality of each guideline was systematically evaluated following the Guidelines for Research and Evaluation II (AGREE II) (24). The AGREE II is one of the most applied tools to assess clinical guidelines in healthcare settings (25-27), and it encompasses a wide variety of quality aspects compared to other tools (28). The AGREE II contains 23 items allocated across six domains: (i) scope and purpose; (ii) stakeholder involvement; (iii) rigor of development; (iv) clarity of presentation; (v) applicability; and (vi) editorial independence. Every domain contains 3-8 items with statements (eg, "the population to whom the guideline is meant to apply is specifically described") that is scored on a scale from 1 (strongly disagree) to 7 (strongly agree) by a minimum of two independent reviewers. On the basis of the ratings, each domain is scored obtaining a scaled score from $0 \%$ (worst possible score) to $100 \%$ (best possible score).

To our knowledge, no quality evaluation tool has been developed and validated for occupational health contexts. Although the AGREE II has been developed to evaluate clinical guidelines for healthcare professionals, most of the items are generic and AGREE II has previously been applied in occupational settings (19) However, we rephrased some of the wording on five items to specify the particular populations or complex interdisciplinary interventions applied in a workplace setting. Additionally, based on problems identified at the weekly consensus meetings, we found it necessary to specify the interpretation within an occupational context on 17 of the 23 items to facilitate interrater reliability (see table 2 for a list of all the AGREE II items and adjusted items).

In this study, a minimum of three independent reviewers scored each guideline. In addition to the
AGREE II scores, we also added a consensus score. Based on a discussion of each of the individual AGREE II ratings, a final score was achieved by reaching consensus of one score that best reflected the appropriate rating. In accordance with the AGREE II manual, we calculated scaled scores for each domain of the AGREE ratings:

Obtained score - Minimum possible score

Maximum possible score - Minimum possible score

The quality of all the guidelines was summarized by categorizing the scaled consensus scores of all domains into four quality levels: high $\geq 80 \%$; moderate: $\leq 79 \%$ and $\geq 65 \%$; moderately low $\leq 64 \%$ and $\geq 50 \%$; poor: $\leq 49 \%$. The developmental quality of guidelines were considered by comparing differences across all AGREE II domains, but guidelines that scored $\geq 65 \%$ (high or moderate) on domains $\mathrm{i}-\mathrm{iii}$ were included in the synthesis. Additionally, the reported evidence underpinning the expected outcomes of recommendations (domain iii) was compared across guidelines.

\section{Results}

From the 1453 documents retrieved by the database search, 52 documents were identified via title/abstract screening (figure 1). None of the documents identified from the database search were guidelines. A few were journal articles that described the guideline development, but helped identify guidelines via the reference lists $(\mathrm{N}=13)$. The same guidelines that were included via the database search were also identified via a Google search or expert advice. A final of 17 guidelines were included for quality assessment.

\section{Comparison of the characteristics of guidelines and recommended interventions}

The guidelines were from Australia, Canada, Denmark, England, New Zealand, Sweden, the Organization for Economic Cooperation and Development (OECD), the World Health Organization (WHO) and were all available online. [See table 3, guideline numbers: 1 (29), 2 (30), 3 (31, 32), 4 (33), 5 (34), 6 (35), 7 (36), 8 (37), $9(38,39)$, 10 (40), 11 (41), 12 (42), 13 (43), 14 (44), 15 (45), 16 (46), 17 (47).] Two were standards, the remaining were characterized as guidelines, guides or recommendations. They were primarily initiated by governmental bodies or occupational health and safety institutions and some were developed in corporation with research institutes. With a few exceptions, the guidelines were generic and intended to guide employers or managers at all types of 
Table 2. AGREE II quality assessment questions. [MHP=mental health problems.] Italics indicate further specifications of items to facilitate understanding of criteria for assessment of guidelines ${ }^{a}$

\begin{tabular}{|c|c|c|}
\hline Domains & Original AGREE II item & Adjustments in formulation of items: Reformulated description ${ }^{b}$ \\
\hline \multirow[t]{3}{*}{$\begin{array}{l}\text { Scope and } \\
\text { purpose }\end{array}$} & $\begin{array}{l}\text { 1. The overall objective(s) of the guideline is (are) } \\
\text { specifically described }\end{array}$ & \\
\hline & $\begin{array}{l}\text { 2. The health question(s) covered by the guideline } \\
\text { is (are) specifically described }\end{array}$ & $\begin{array}{l}\text { The specific assumptions and expected effect achieved by implementing the guideline is/ } \\
\text { are specifically described }\end{array}$ \\
\hline & $\begin{array}{l}\text { 3. The population (patients, public, etc.) to whom the } \\
\text { guideline is meant to apply is specifically described }\end{array}$ & $\begin{array}{l}\text { The population or groups eg, employees at risk of developing MHP, employees with MHP } \\
\text { etc. to whom the guideline is meant to apply is specifically described. In this case the pop- } \\
\text { ulation do not refer to the groups of people who should implement the interventions }\end{array}$ \\
\hline \multirow[t]{3}{*}{$\begin{array}{l}\text { Stakeholder } \\
\text { involvement }\end{array}$} & $\begin{array}{l}\text { 4. The guideline development group includes } \\
\text { individuals from all relevant professional groups }\end{array}$ & $\begin{array}{l}\text { Examples of relevant professional groups: Worker representatives, employer from selected } \\
\text { organizations, managers, occupational health professionals, representatives from the } \\
\text { social system }\end{array}$ \\
\hline & $\begin{array}{l}\text { 5. The views and preferences of the target population } \\
\text { (patients, public, etc.) have been sought }\end{array}$ & $\begin{array}{l}\text { Target population is: employees/individuals with occupational health problems, employee } \\
\text { representatives }\end{array}$ \\
\hline & 6. The target users of the guideline are clearly defined & $\begin{array}{l}\text { The appointed individuals/groups at the workplace who are responsible for implementing } \\
\text { the guideline }\end{array}$ \\
\hline \multirow[t]{8}{*}{$\begin{array}{l}\text { Rigor of } \\
\text { development }\end{array}$} & $\begin{array}{l}\text { 7. Systematic methods were used to search for } \\
\text { evidence }\end{array}$ & $\begin{array}{l}\text { In case of complex interventions targeting different groups of employees, eg, primary and } \\
\text { tertiary interventions, were systematic methods used to search for all relevant evidence? }\end{array}$ \\
\hline & $\begin{array}{l}\text { 8. The criteria for selecting the evidence are clearly } \\
\text { described }\end{array}$ & $\begin{array}{l}\text { In case of selective review instead of systematic: Are the inclusion and exclusion criteria for } \\
\text { selecting the evidence clearly described? }\end{array}$ \\
\hline & $\begin{array}{l}\text { 9. The strengths and limitations of the body of } \\
\text { evidence are clearly described }\end{array}$ & $\begin{array}{l}\text { Specific focus on whether limitations of current level of underlying evidence have been } \\
\text { clearly described eg, lack of feasibility and effectiveness evaluation of the recommended } \\
\text { workplace interventions }\end{array}$ \\
\hline & $\begin{array}{l}\text { 10. The methods for formulating the } \\
\text { recommendations are clearly described }\end{array}$ & Description of systematic process or specific methods, for example Delphi, Glaser \\
\hline & $\begin{array}{l}\text { 11. The health benefits, side effects, and risks have } \\
\text { been considered in formulating the recommendations }\end{array}$ & $\begin{array}{l}\text { Possible health or work related consequences and risks have been considered in formulat- } \\
\text { ing the recommendations. If not written directly: Is it reflected in the guideline, eg }, \text { consid- } \\
\text { erations about how to respect employee confidentiality }\end{array}$ \\
\hline & $\begin{array}{l}\text { 12. There is an explicit link between the } \\
\text { recommendations and the supporting evidence }\end{array}$ & \\
\hline & $\begin{array}{l}\text { 13. The guideline has been externally reviewed by } \\
\text { experts prior to its publication }\end{array}$ & \\
\hline & 14. A procedure for updating the guideline is provided & Relevant if stated in any of the published documents \\
\hline \multirow[t]{4}{*}{$\begin{array}{l}\text { Clarity of } \\
\text { presentation }\end{array}$} & $\begin{array}{l}\text { 15. The recommendations are specific and } \\
\text { unambiguous }\end{array}$ & $\begin{array}{l}\text { Considering complex interventions: Precise description of which intervention should be } \\
\text { undertaken by who and how it works under which people under which circumstances }\end{array}$ \\
\hline & $\begin{array}{l}\text { 16. The different options for management of the } \\
\text { condition or health issue are clearly presented }\end{array}$ & $\begin{array}{l}\text { The recommended interventions are adequate and realistic considering the targeted occu- } \\
\text { pational health problem/condition }\end{array}$ \\
\hline & & Considering complex interventions: Do the guide deliver solutions to the problems \\
\hline & 17. Key recommendations are easily identifiable & \\
\hline \multirow[t]{4}{*}{ Applicability } & $\begin{array}{l}\text { 18. The guideline describes facilitators and barriers } \\
\text { to its application }\end{array}$ & All available documents are considered \\
\hline & $\begin{array}{l}\text { 19. The guideline provides advice and/or tools on how } \\
\text { the recommendations can be put into practice }\end{array}$ & $\begin{array}{l}\text { eg, health literacy programs, dialogue tools, procedures or refer to places or human re- } \\
\text { sources that aid implementation. }\end{array}$ \\
\hline & $\begin{array}{l}\text { 20. The potential resource implications of applying } \\
\text { the recommendations have been considered }\end{array}$ & eg, training of employees, external consultancy, psychological, psychiatric aid \\
\hline & $\begin{array}{l}\text { 21. The guideline presents monitoring and/ or } \\
\text { auditing criteria }\end{array}$ & $\begin{array}{l}\text { The guideline presents ways to assess whether and/or how the intervention works eg, tools } \\
\text { to evaluate cases or surveys of health related and work related outcomes. }\end{array}$ \\
\hline \multirow[t]{2}{*}{$\begin{array}{l}\text { Editorial } \\
\text { independence }\end{array}$} & $\begin{array}{l}\text { 22. The views of the funding body have not influenced } \\
\text { the content of the guideline }\end{array}$ & eg, a statement of whether the financing parties have influenced the guidelines \\
\hline & $\begin{array}{l}\text { 23. Competing interests of guideline development } \\
\text { group members have been recorded and addressed }\end{array}$ & eg, a statement clarifying competing interests \\
\hline
\end{tabular}

\footnotetext{
a The ratings were compared and scored at weekly consensus meetings and differences in interpretations of specific items were noted. To aid similar interpretation of the items we specified the criteria.

${ }^{\mathrm{b}}$ The occupational health interventions were complex and often used an interdisciplinary approach combining organizational, health and psychosocial aspects. The
} AGREE II items were not always adaptable to an occupational context and formulations had to be adjusted accordingly. 


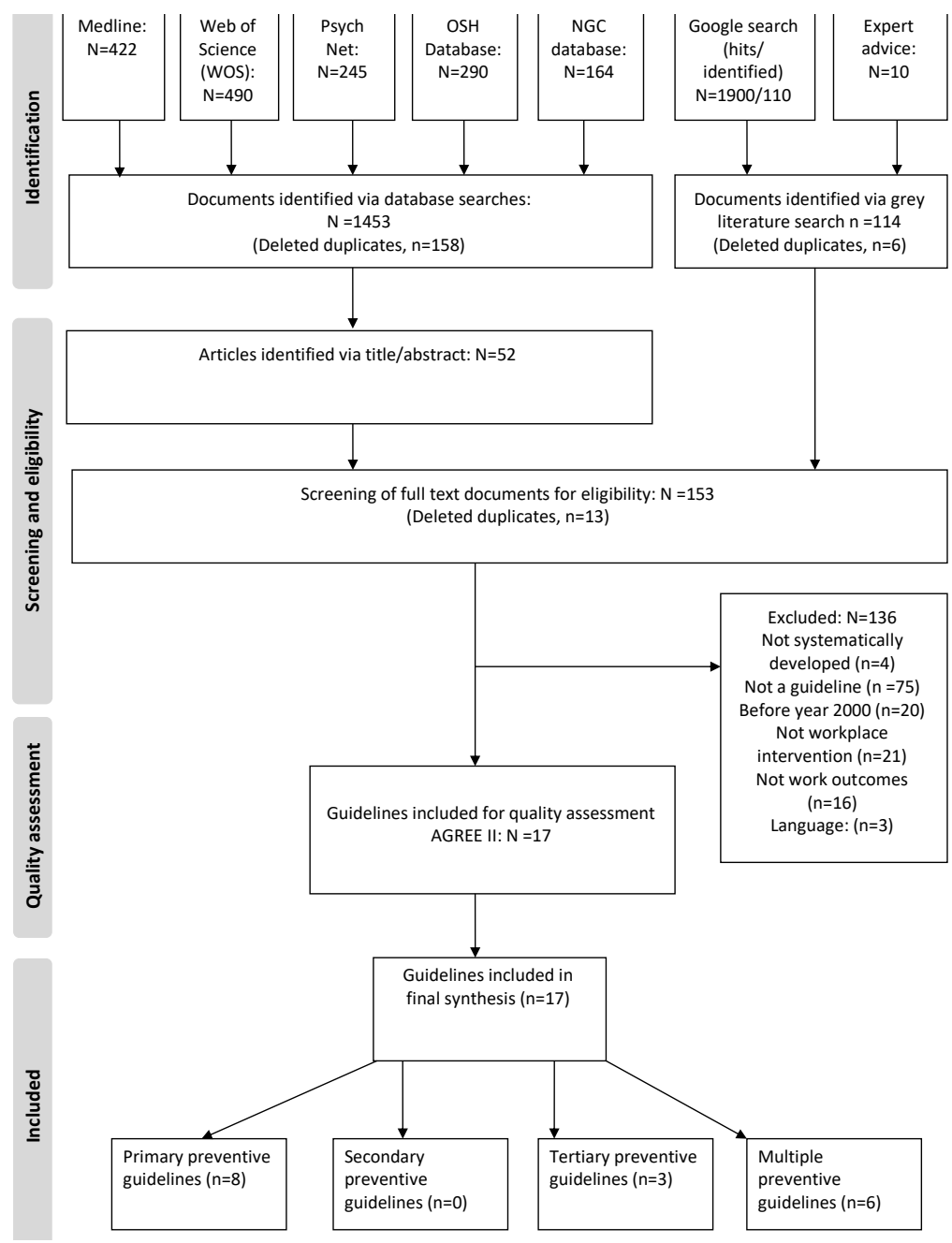

Figure 1. Flow-chart of review process.

workplaces irrespective of size or sector. Eight guidelines had focused on primary prevention, three on tertiary prevention, and six combined primary, secondary and tertiary interventions to achieve the desired effects. None of the guidelines identified in this review had focused solely on secondary prevention.

\section{Primary preventive guidelines}

Recommendations for employers. All eight guidelines recommended that the employer should be responsible for implementing interventions at the organizational level (guideline numbers 1-8, table 4 ). The first one was a mental risk management procedure that continuously and systematically identified and eliminated psychosocial risks. Although the frameworks differed they all recommended that employers should implement a risk management procedure in following steps: (i) make a business case to ensure commitment from management and staff; (ii) develop a mental health policy including a systematic strategy to improve organizational mental health and ensure commitment from all levels in the organization; (iii) involve workers from all levels of the organization and develop a plan, appoint resources, roles and responsibilities; (iv) implement a system that systematically identifies psychosocial hazards of the workplace. These could be organizational (eg, workloads), relational (eg, conflict with manager), or work itself (eg, threats from client); (v) develop and implement a plan that promote positive factors in the work environment and eliminate or reduce the adverse. If possible, the plan should be integrated in existing Occupational Health and Safety (OHS) infrastructure; and (vi) evaluate and adjust the plan continuously.

Most guidelines also recommended that employers should implement educational programs to prevent the stigma commonly associated with MHP. Five guidelines also emphasized the special role that first line managers can have in preventing MHP and recommended management training to improve their relational, com- 
Table 3. Data extraction of characteristics of guidelines included in review $(\mathrm{N}=17)$ [?=not specified; Generic=all types of workplace irrespective of size or sector; $\mathrm{OHS}=$ occupational health service; $\mathrm{RTW}=$ return to work]

\begin{tabular}{|c|c|c|c|c|c|c|}
\hline Guideline details & $\begin{array}{l}\text { Guideline } \\
\text { type }\end{array}$ & $\begin{array}{l}\text { Target population } \\
\text { (specified target } \\
\text { groups) }\end{array}$ & $\begin{array}{l}\text { Target } \\
\text { population(s) of } \\
\text { recommended } \\
\text { interventions }\end{array}$ & $\begin{array}{l}\text { Method(s) to develop } \\
\text { evidence-based } \\
\text { recommendations }\end{array}$ & $\begin{array}{l}\text { Procedure(s) } \\
\text { to involve } \\
\text { stakeholders }\end{array}$ & $\begin{array}{l}\text { Expected main effects of interventions } \\
\downarrow=\text { Reduced } \\
\uparrow=\text { Improved }\end{array}$ \\
\hline
\end{tabular}

Guidelines recommending primary preventive interventions ( $\mathrm{N}=8)$

\begin{tabular}{|c|c|c|c|c|}
\hline $\begin{array}{l}\text { 1. Canadian stan- } \\
\text { dard, Mental Health } \\
\text { Commission and } \\
\text { Standards Council of } \\
\text { Canada; Canada, } 2013\end{array}$ & $\begin{array}{l}\text { Standard (3 } \\
\text { levels: shall, } \\
\text { should, may) }\end{array}$ & $\begin{array}{l}\text { Generic (mainly } \\
\text { top management, } \\
\text { HR, owner or senior } \\
\text { manager if small } \\
\text { company) }\end{array}$ & $\begin{array}{l}\text { All employees } \\
\text { All first line } \\
\text { managers }\end{array}$ & $\begin{array}{l}\text { Peer-reviewed selective } \\
\text { review of link between } \\
\text { occupational risk fac- } \\
\text { tors and MH/Review of } \\
\text { legislation }\end{array}$ \\
\hline $\begin{array}{l}\text { 2. CA Ontario Guide, } \\
\text { Canadian Mental } \\
\text { Health Association, } \\
\text { Ontario \& University } \\
\text { of Toronto; Canada, } \\
\text { publication year (?) }\end{array}$ & Guide & $\begin{array}{l}\text { Generic (first line } \\
\text { managers) }\end{array}$ & $\begin{array}{l}\text { All employees } \\
\text { All first line } \\
\text { managers }\end{array}$ & $\begin{array}{l}\text { Selective review of occu- } \\
\text { pational risk factors and } \\
\text { factors affecting, MH } \\
\text { and work disability }\end{array}$ \\
\hline $\begin{array}{l}\text { 3. AU Prevent, } \\
\text { University of } \\
\text { Melbourne; Australia, } \\
2013\end{array}$ & Guideline & $\begin{array}{l}\text { Generic (mainly } \\
\text { senior and first line } \\
\text { managers) }\end{array}$ & $\begin{array}{l}\text { All employees } \\
\text { All first line } \\
\text { managers }\end{array}$ & Selective review of (?) \\
\hline $\begin{array}{l}\text { 4. NICE UK, National } \\
\text { Institute for Health and } \\
\text { Care Excellence, UK; } \\
2009\end{array}$ & Guideline & $\begin{array}{l}\text { Generic (mainly } \\
\text { employers and their } \\
\text { representatives) }\end{array}$ & $\begin{array}{l}\text { All employees } \\
\text { All first line } \\
\text { managers }\end{array}$ & $\begin{array}{l}\text { Systematic and thematic } \\
\text { reviews of effective- } \\
\text { ness of interventions/ } \\
\text { cost benefit analyses/ } \\
\text { Occupational field work }\end{array}$ \\
\hline $\begin{array}{l}\text { 5. HSE UK, Health \& } \\
\text { Safety Executive, UK, } \\
\text { publication year (?) }\end{array}$ & Standard & $\begin{array}{l}\text { Large organiza- } \\
\text { tions }>50 \text { employees } \\
\text { (Owner, board direc- } \\
\text { tor; top manage- } \\
\text { ment and first line } \\
\text { managers) }\end{array}$ & $\begin{array}{l}\text { All employees } \\
\text { All first line } \\
\text { managers }\end{array}$ & $\begin{array}{l}\text { Scoping review, } \\
\text { pilot study to test } \\
\text { implementation }\end{array}$ \\
\hline $\begin{array}{l}\text { 6. Karolinska SW, } \\
\text { Karolinska Institutet; } \\
\text { Occupational health } \\
\text { professional union; } \\
\text { Sweden, } 2015\end{array}$ & Guideline & $\begin{array}{l}\text { Generic (mainly } \\
\text { employers and } \mathrm{OHS} \\
\text { professionals) }\end{array}$ & $\begin{array}{l}\text { All employees } \\
\text { All first line } \\
\text { managers }\end{array}$ & $\begin{array}{l}\text { Systematic review of } \\
\text { effect of workplace } \\
\text { interventions; }\end{array}$ \\
\hline $\begin{array}{l}\text { 7. WHO Prima, } \\
\text { WHO PRIMA-EF } \\
\text { consortium; World } \\
\text { Health Organization, } \\
2008\end{array}$ & Guide & $\begin{array}{l}\text { Generic. Also focus } \\
\text { on work with high } \\
\text { risk of violence by } \\
\text { third parties (em- } \\
\text { ployers and worker } \\
\text { representatives) }\end{array}$ & $\begin{array}{l}\text { All employees } \\
\text { All first line } \\
\text { managers }\end{array}$ & $\begin{array}{l}\text { Selective review of } \\
\text { standards/directives; } \\
\text { European Council } \\
\text { Framework Directive; }\end{array}$ \\
\hline $\begin{array}{l}\text { 8. WHO policy, } \\
\text { World Health } \\
\text { Organization; } 2005\end{array}$ & Guide & $\begin{array}{l}\text { Generic (policymak- } \\
\text { ers, planners and } \\
\text { top-management) }\end{array}$ & $\begin{array}{l}\text { All employees } \\
\text { Top-management } \\
\text { (strategic and } \\
\text { policy making } \\
\text { level) }\end{array}$ & $\begin{array}{l}\text { Expert opinion of MH } \\
\text { and OHS praction- } \\
\text { ers and researchers, } \\
\text { business }\end{array}$ \\
\hline
\end{tabular}

Systematic $\downarrow$ Work related MHP, mental injuries, consen- accidents, costs, sickness absence.

sus process $\uparrow \mathrm{MH}$, work culture, productivity, orwith key ganizational excellency, recruitment, stakeholders retention

$\downarrow$ Work related MHP, injuries, sickness absence, stigma, costs

$\uparrow \mathrm{MH}, \mathrm{MH}$ literacy, productivity, worker morale, job satisfaction, retention, creativity, recruitment

Peer reviewed $\downarrow$ Work related MHP

Delphi study with key stakeholder

$\uparrow \mathrm{MH}$, positive psychosocial factors at work

Informal consensus process with key stakeholders

$\downarrow$ Work related MHP, sickness absence early retirement, turnover, costs

$\uparrow \mathrm{MH}$; job satisfaction, commitment productivity, legal requirements, performance, organizational excellency $\downarrow$ Work related MHP, Sickness absence $\uparrow \mathrm{MH}$; Organizational performance; productivity

Involvement $\quad \downarrow$ Costs, sickness absence

of key stake- $\uparrow$ Productivity; performance; work holders in demands, leadership; social climate development demands, leability, symptoms wellbeing of research questions

Consensus $\quad \downarrow$ Work related MHP; bullying; sickness process with absence; injuries; medical expenses; selected $\mathrm{OHS}$ insurance premiums; enterprise cost institutes from 2004 and 2007

$\uparrow \mathrm{MH}$; Innovation; productivity; quality of work; practices; communication; effectiveness, efficiency (?) $\downarrow \mathrm{MHP}$, costs $\uparrow$ mental health; MH literacy

Guidelines recommending tertiary preventive interventions $(\mathrm{N}=3)$

\author{
9. CA Montreal, \\ Laval Montreal, \\ The Institut de recher- \\ ché Robert-Sauvé et \\ en sécurité du travail; \\ Université Laval \\ Canada; 2014 \\ 10. OHS CA BC; \\ Occupational Health \\ and Safety Agency for \\ Healthcare, Canada; \\ 2010
}

11. AU RTW; Center

for Youth Mental

Health, University of

Melbourne; Australia;

2011
Guide

Generic (Company

executives, manag- ployees due to

ers, $\mathrm{HR}$, work place MHP

union groups and $\mathrm{OH}$ All levels of

practitioners) $\quad$ Management

Best practice Generic guideline

Guideline Generic
Sick-listed employees due to MHP

All levels of

Management

Sick-listed employees MHP

All levels of management
Selective review; best practice study;

Systematic consensus process with key stakeholders/30 interviews

Systematic review of workplace interventions involveand their effectiveness ment of key (in accordance with NICE stakeholders guideline development)

Selective review of (?)

Peer reviewed $\downarrow$ Stigma, costs, sickness absence Delphistudy including key stakeholders $\downarrow$ Stigma

$\uparrow \mathrm{MH}$; shared and coordinated goals; commitment and positive attitudes towards workers with MHP; organizational learning: Relational skills of managers

$\downarrow$ Costs, sickness absence

$\uparrow Q 0 L$, quality of work, retention

$\uparrow$ Productivity 
Table 3. continued

\begin{tabular}{|c|c|c|c|c|c|c|}
\hline Guideline details & $\begin{array}{l}\text { Guideline } \\
\text { type }\end{array}$ & $\begin{array}{l}\text { Target population } \\
\text { (specified target } \\
\text { groups) }\end{array}$ & $\begin{array}{l}\text { Target } \\
\text { population(s) of } \\
\text { recommended } \\
\text { interventions }\end{array}$ & $\begin{array}{l}\text { Method(s) to develop } \\
\text { evidence-based } \\
\text { recommendations }\end{array}$ & $\begin{array}{l}\text { Procedure(s) } \\
\text { to involve } \\
\text { stakeholders }\end{array}$ & $\begin{array}{l}\text { Expected main effects of interventions } \\
\downarrow=\text { Reduced } \\
\uparrow=\text { Improved }\end{array}$ \\
\hline \multicolumn{7}{|c|}{ Guidelines combining primary, secondary or tertiary preventive interventions $(N=6)^{\text {a }}$} \\
\hline \multirow{2}{*}{$\begin{array}{l}\text { 12. CA Vancouver; } \\
\text { The Centre for Applied } \\
\text { Research, Vancouver; } \\
\text { Mental Health } \\
\text { Commission of Canada } \\
\text { Ontario; Canada, } 2012\end{array}$} & \multirow{2}{*}{$\begin{array}{l}\text { Best practice } \\
\text { recommen- } \\
\text { dations and } \\
\text { guide }\end{array}$} & \multirow{2}{*}{$\begin{array}{l}\text { Generic (mainly } \\
\text { employers and HR } \\
\text { personnel) }\end{array}$} & $\begin{array}{l}\text { All employees/ } \\
\text { Emplovees sick- }\end{array}$ & \multirow{2}{*}{$\begin{array}{l}\text { Selective review and } \\
\text { analysis of models for } \\
\text { improving workplace } \\
\text { mental health }\end{array}$} & \multirow{2}{*}{$\begin{array}{l}\text { Involvement } \\
\text { of scientific } \\
\text { and OHP ex- } \\
\text { pert opinion }\end{array}$} & $\begin{array}{l}\downarrow \text { Work related MHP, stigma, costs, } \\
\text { sickness absence }\end{array}$ \\
\hline & & & $\begin{array}{l}\text { listed due to } \\
\text { MHPIAll levels of } \\
\text { Management }\end{array}$ & & & $\begin{array}{l}\uparrow \text { Productivity; well-being; employee } \\
\text { resilience; work environment; work/ } \\
\text { home balance }\end{array}$ \\
\hline \multirow{2}{*}{$\begin{array}{l}\text { 13. NRCWE CK, } \\
\text { National Research } \\
\text { Center of the Working } \\
\text { Environment; } \\
\text { Denmark, } 2010\end{array}$} & \multirow{2}{*}{$\begin{array}{l}\text { Best practice } \\
\text { recommenda- } \\
\text { tions }\end{array}$} & \multirow[t]{2}{*}{ Generic } & All employees/ & \multirow{2}{*}{$\begin{array}{l}\text { Systematic review of in- } \\
\text { cidence of work related } \\
\text { MHP, prevention of work } \\
\text { related MHP, effect of } \\
\text { RTW interventions }\end{array}$} & \multirow{2}{*}{$\begin{array}{l}\text { Involvement } \\
\text { of scien- } \\
\text { tific and OHS } \\
\text { experts }\end{array}$} & \multirow{2}{*}{$\begin{array}{l}\downarrow \text { Work related MHP, sickness absence } \\
\uparrow \mathrm{MH}\end{array}$} \\
\hline & & & $\begin{array}{l}\text { Employees sick- } \\
\text { listed due to } \\
\text { MHP/All levels of } \\
\text { Management }\end{array}$ & & & \\
\hline \multirow{2}{*}{$\begin{array}{l}\text { 14. MH AU, Mental } \\
\text { Health Commission AU, } \\
\text { National Mental Health } \\
\text { Commission \& Mentally } \\
\text { Healthy Workplace } \\
\text { Alliance; Australia; } \\
2014\end{array}$} & \multirow{2}{*}{$\begin{array}{l}\text { Best practice } \\
\text { recommenda- } \\
\text { tions }\end{array}$} & \multirow[t]{2}{*}{ Generic } & All employees/ & \multirow[t]{2}{*}{$\begin{array}{l}\text { Selective review with } \\
\text { graded evidence }\end{array}$} & \multirow[t]{2}{*}{ (?) } & $\begin{array}{l}\downarrow \text { Work related MHP, injuries, stigma, } \\
\text { costs, sickness absence }\end{array}$ \\
\hline & & & $\begin{array}{l}\text { listed due to } \\
\text { MHPIAll levels of } \\
\text { Management }\end{array}$ & & & $\begin{array}{l}\uparrow M H ; \text { individual resilience; } \\
\text { productivity; }\end{array}$ \\
\hline \multirow{2}{*}{$\begin{array}{l}\text { 15. Public Sector } \\
\text { AU, Australian Public } \\
\text { Service Commission; } \\
\text { Comcare; Australia, } \\
\text { publication year (?) }\end{array}$} & \multirow[t]{2}{*}{ Guide } & \multirow[t]{2}{*}{$\begin{array}{l}\text { Managers in public } \\
\text { sector }\end{array}$} & All employees/ & \multirow{2}{*}{$\begin{array}{l}\text { Selective review (?); } \\
\text { Case study of selected } \\
\text { EU countries and EU } \\
\text { legislation }\end{array}$} & \multirow[t]{2}{*}{ (?) } & $\begin{array}{l}\downarrow \text { Work related MHP; injuries; stigma, } \\
\text { costs, sickness absence }\end{array}$ \\
\hline & & & $\begin{array}{l}\text { listed due to } \\
\text { MHP/first line } \\
\text { manager }\end{array}$ & & & $\begin{array}{l}\uparrow M H ; \text { quality of leadership; } \\
\text { productivity }\end{array}$ \\
\hline \multirow{2}{*}{$\begin{array}{l}\text { 16. OSH NZ, } \\
\text { Occupational Safety } \\
\text { and Health Service, } \\
\text { Department of Labour, } \\
\text { Wellington; New } \\
\text { Zealand, } 2003\end{array}$} & \multirow[t]{2}{*}{ Guideline } & \multirow{2}{*}{$\begin{array}{l}\text { Generic, main focus } \\
\text { on workplaces with } \\
\text { non-modifiable risk } \\
\text { factors (e.g. police } \\
\text { force, hospitals) }\end{array}$} & All employees/ & \multirow{2}{*}{$\begin{array}{l}\text { Selective review (from } \\
\text { previous guideline pub- } \\
\text { lished in year 2000) }\end{array}$} & \multirow[t]{2}{*}{ (?) } & \multirow{2}{*}{$\begin{array}{l}\downarrow \text { Sickness absence; work related } \\
\text { stress; injuries }\end{array}$} \\
\hline & & & $\begin{array}{l}\text { Employees sick- } \\
\text { listed due to } \\
\text { MHP/first line } \\
\text { management }\end{array}$ & & & \\
\hline \multirow{3}{*}{$\begin{array}{l}\text { 17. European } \\
\text { Commission; } \\
\text { European Commission; } \\
2014\end{array}$} & \multirow[t]{3}{*}{ Guideline } & \multirow{3}{*}{$\begin{array}{l}\text { Generic (employers, } \\
\text { employees, trade } \\
\text { unions, policy mak- } \\
\text { ers or professionals) }\end{array}$} & All employees/ & \multirow{3}{*}{$\begin{array}{l}\text { Selective review of (?); } \\
\text { Case study of select EU } \\
\text { countries implementa- } \\
\text { tion of EU directive }\end{array}$} & \multirow[t]{3}{*}{ (?) } & \multirow{2}{*}{$\begin{array}{l}\downarrow \text { Work MHP, injuries, sickness ab- } \\
\text { sence, organizational costs (health and } \\
\text { social insurers) }\end{array}$} \\
\hline & & & $\begin{array}{l}\text { Employees sick- } \\
\text { listed due to }\end{array}$ & & & \\
\hline & & & $\begin{array}{l}\text { MHP/first line } \\
\text { management }\end{array}$ & & & $\begin{array}{l}\uparrow \text { Productivity; quality of work; return } \\
\text { to work; job-person fit; retention }\end{array}$ \\
\hline
\end{tabular}

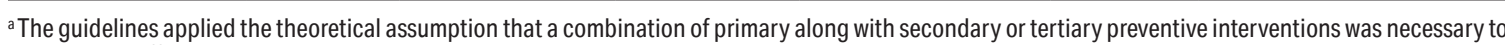
achieve the effects.

municative, and job-design skills to minimize employee stress (guideline numbers $1-5$, table 4 ). The guidelines reported that implementing these two interventions could reduce incidence of work-related MHP and following sickness absence and related costs. A few also expected an impact on organizational excellency and ability to retain workers.

Evidence of primary preventive interventions. Only two guidelines reported that their recommendations were based on a systematic review (guideline number 4 and 6 , table 3 ). The remaining guidelines selected evidence to support statements without considering limitations or contradictory evidence. However, the content of the main recommendations was similar, and the same studies were used to validate statements. The evidence of the management procedure was mainly underpinned by epidemiological studies showing that poorly organized work (eg, job strain from low job control and high demands, stressors intrinsic to the job such as threats of violence by clients), and poor management and/or work climate (eg, workplace bullying, conflicts) increased employees' risk of developing health problems, such as stress, depression or cardiovascular diseases. Also, evidence suggests that positive work factors (collegial support, rewards, meaning and cohesion) promote well-being (10). Although some work and health related gains could be expected from reducing modifiable adverse work factors (48), the reported effectiveness of implementing the recommended risk management procedure remained undocumented. Similarly, it is not yet possible to identify effective interventions to reduce stigma at the workplace (49). One guideline had provided a cost-benefit analysis (number 4), but the reduced organizational costs expected by most of the guidelines were not documented. Only two guidelines acknowledged the limited evidence available to document the expected effect of implementing recommendations (numbers 4 and 5). 
Table 4. Overview of main interventions recommended by guidelines. [T=tools facilitating implementation of recommendations either provided in guideline or via links to external resources; $F=$ framework explaining the theoretical mechanisms underpinning the recommendation; $E V B=e v i d e n c e$ based; RTW=return to work; $0=$ organization; $\mathrm{M}=$ management; $\mathrm{MH}=$ mental health; $\mathrm{MHP}=\mathrm{MH}$ problem; $\mathrm{OHP}=$ occupational health; $\mathrm{SMT}=$ stress management training]

\begin{tabular}{|c|c|c|c|c|c|c|c|c|c|c|c|c|c|c|c|c|c|}
\hline \multirow[t]{2}{*}{$\begin{array}{l}\text { Level of prevention } \\
\text { (responsibility for } \\
\text { implementation) }\end{array}$} & \multicolumn{17}{|c|}{$\begin{array}{c}\text { Guideline [1= CA Standard; } 2=\text { CA Ontario; } 3=\text { AU Prevent; } 4=\text { =NICE UK; } 5=\text { HSE UK; } 6=\text { Karolinska SW; } \\
\text { 7= WHO Prima; } 8=\text { =WHO policy; } 9=\text { =CA Montreal; } 10=\mathrm{OHS} \mathrm{CA} ; 11=\text { AU RTW; } 12=\text { =CA Vancouver; } \\
\text { 13=NRCWE DK; } 14=\mathrm{MH} \mathrm{AU;} 15=\text { Public AU; } 16=\mathrm{OHS} \mathrm{NZ;} 17=\text { European Commission }]\end{array}$} \\
\hline & 1 & 2 & 3 & 4 & 5 & 6 & 7 & 8 & 9 & 10 & 11 & 12 & 13 & 14 & 15 & 16 & 17 \\
\hline \multicolumn{18}{|l|}{ Primary preventive interventions } \\
\hline $\begin{array}{l}\text { OH risk management procedures } \\
\text { of all employees (O/top } \mathrm{M})\end{array}$ & $\mathcal{J}(\mathrm{F} / \mathrm{T})$ & $\checkmark(\mathrm{T})$ & $\checkmark$ & $J(\mathrm{~T})$ & $\mathcal{J}(\mathrm{T})$ & $\checkmark(F / T) \checkmark$ & $(\mathrm{F} / \mathrm{T})$ & $\mathcal{J}(\mathrm{F})$ & & & & $\checkmark(F / T)$ & $\checkmark$ & $\checkmark(F)$ & $\checkmark$ & $\checkmark$ & $\mathcal{J}(\mathrm{F})$ \\
\hline $\begin{array}{l}\text { MH literacy/first aid programs to } \\
\text { all employee (O/top M) }\end{array}$ & $\checkmark(\mathrm{F} / \mathrm{T})$ & $\checkmark(\mathrm{T})$ & $\checkmark$ & & $\checkmark(\mathrm{T})$ & $\sqrt{ }(\mathrm{F} / \mathrm{T})$ & & $\checkmark$ & $\checkmark$ & $\checkmark$ & $\checkmark$ & $\checkmark(\mathrm{T})$ & $\checkmark$ & $\checkmark(\mathrm{F})$ & $\checkmark(\mathrm{T})$ & & $\checkmark$ \\
\hline $\begin{array}{l}\text { MH relational and communication } \\
\text { skills of all first line } \mathrm{M}(\mathrm{O} / \text { top } \mathrm{M})\end{array}$ & $\mathcal{J}(\mathrm{F} / \mathrm{T})$ & $\checkmark(\mathrm{T})$ & $\checkmark$ & $\sqrt{ }(\mathrm{T})$ & $\checkmark(\mathrm{T})$ & & & & $\checkmark$ & $\checkmark$ & $\checkmark$ & $\checkmark$ & & $\checkmark$ & & & \\
\hline $\begin{array}{l}\text { Employee resilience procedures } \\
\text { and training (O/top M/ first line } \mathrm{M})\end{array}$ & & & & & & & & & & & & $\checkmark(\mathrm{T})$ & & $\mathcal{J}(\mathrm{F})$ & & $\checkmark(\mathrm{T})$ & $\checkmark$ \\
\hline \multicolumn{18}{|l|}{ Secondary preventive interventions } \\
\hline $\begin{array}{l}\text { Screening of all employees (0)/M } \\
\text { training in MHP detection of MHP } \\
\text { and management of signs of MHP } \\
\text { in employees ( } 0 / \text { Top M) }\end{array}$ & & & & & & & & & & & & $\checkmark$ & $\checkmark$ & $\checkmark$ & $\checkmark$ & & \\
\hline \multicolumn{18}{|l|}{$\begin{array}{l}\text { Tertiary preventive interventions } \\
\text { for employees with MHP (level of re- } \\
\text { sponsibility for implementation) }\end{array}$} \\
\hline $\begin{array}{l}\text { Procedures to facilitate EVB treat- } \\
\text { ment (0/top M/first line M) }\end{array}$ & & & & & $\checkmark$ & & & & $\checkmark(\mathrm{F})$ & $\checkmark$ & & $\mathcal{J}(\mathrm{T})$ & $\checkmark$ & $\checkmark$ & $\checkmark(\mathrm{T})$ & & \\
\hline $\begin{array}{l}\text { Stay at work adjustments } \\
\text { (first line M) }\end{array}$ & & & & & & & & & $\checkmark(\mathrm{F})$ & $\checkmark$ & $\checkmark$ & $\checkmark(\mathrm{T})$ & $\checkmark(F)$ & $\checkmark$ & $\checkmark$ & & \\
\hline $\begin{array}{l}\text { Employee SMT (0/top M/first } \\
\text { line M) }\end{array}$ & & & & & & & & & & $\checkmark$ & & $\checkmark(\mathrm{T})$ & & $\checkmark(F)$ & & & \\
\hline $\begin{array}{l}\text { RTW policies procedures, plans } \\
\text { (O/top M) }\end{array}$ & & & & & & & & & $\checkmark(F)$ & $\checkmark(F$ & $\checkmark$ & $\checkmark(\mathrm{T})$ & $\checkmark$ & $\checkmark$ & $\checkmark(\mathrm{T})$ & $\sqrt[J]{ }(\mathrm{T})$ & $\checkmark$ \\
\hline $\begin{array}{l}\text { Coordinated disability } \\
\text { management (first line M or } \\
\text { RTW coordinator) }\end{array}$ & & & & & & & & & $\checkmark(\mathrm{F})$ & $\checkmark(F$ & & $\checkmark(\mathrm{T})$ & $\checkmark$ & & $\checkmark(\mathrm{T})$ & & \\
\hline $\begin{array}{l}\text { Work counselling ( } \mathrm{O} / \text { top M/first } \\
\text { line } \mathrm{M} \text { and } \mathrm{OH} / \mathrm{MH} \text { professional) }\end{array}$ & & & & & $\checkmark(\mathrm{T})$ & & & & $\checkmark(\mathrm{F})$ & $\checkmark$ & & $\checkmark$ & $\checkmark$ & $\checkmark$ & & & \\
\hline $\begin{array}{l}\text { Gradual RTW (first line M and/or } \\
\mathrm{OH} / \mathrm{MH} \text { professional) }\end{array}$ & & & & & & & & & $\checkmark(\mathrm{F})$ & & & $\checkmark$ & $\checkmark$ & $\checkmark$ & & & \\
\hline $\begin{array}{l}\text { Peer support/mentoring (first line } \\
\text { M/colleagues) }\end{array}$ & & & & & & & & & $\checkmark(F)$ & $\checkmark$ & $\checkmark$ & & $\checkmark$ & $\checkmark$ & & $\checkmark$ & \\
\hline \multicolumn{18}{|l|}{ Combined approach } \\
\hline $\begin{array}{l}\text { Guideline must combine primary } \\
\text { along with secondary or tertiary to } \\
\text { achieve effects }\end{array}$ & & & & & & $\checkmark^{\text {a }}$ & & & & & & $\checkmark$ & $\checkmark$ & $\checkmark$ & $\checkmark$ & $\checkmark$ & $\checkmark$ \\
\hline
\end{tabular}

${ }^{a}$ Guideline recommended a combined approach but only the primary preventive interventions were eligible for inclusion in this review.

\section{Tertiary preventive guidelines}

Recommendations for employers. Three guidelines recommended RTW interventions primarily at the organizational level (guideline numbers 9-11, table 4.). All the guidelines stated that the organization should prepare administrative procedures in case of sick-listing due to MHP. The organization should either appoint a RTW coordinator (guideline numbers 9,10 ) or instruct the first line manager (number 11), who was responsible for a RTW plan, to ensure engagement of the employee and coordinate goals for RTW (eg, gradual RTW, work adjustments) shared by all relevant stakeholders (eg, representatives from health system, social system and workplace) during the sick-leave period.
To properly rehabilitate and prevent relapse, two guidelines recommended that employers implemented programs to increase health literacy of all staff and improved job design and communication competences of managers (eg, active listening skills) for the sick-listed employee and made counselling available to resolve any workplace conflicts or provide individual disability management. Despite differences of healthcare systems, most countries experienced challenges with access to evidence based treatment and guidelines therefore recommended that the organizations should facilitate access.

Recommendations for first line managers. First line managers were responsible for informing and engaging 
Table 5. Overview of the scaled AGREE II ratings and consensus ratings ( $0=$ =worst possible score; $100 \%$ =best possible score) of the 17 included guidelines. [Con=consensus AGREE II scores]

\begin{tabular}{|c|c|c|c|c|c|c|c|c|c|c|c|c|}
\hline \multirow{3}{*}{$\begin{array}{l}\text { Guideline number and } \\
\text { keywords }\end{array}$} & \multicolumn{12}{|c|}{ AGREE II domains scores } \\
\hline & \multicolumn{2}{|c|}{$\begin{array}{l}\text { Scope and } \\
\text { purpose }\end{array}$} & \multicolumn{2}{|c|}{$\begin{array}{l}\text { Stakeholder } \\
\text { involvement }\end{array}$} & \multicolumn{2}{|c|}{$\begin{array}{c}\text { Rigor of } \\
\text { development }\end{array}$} & \multicolumn{2}{|c|}{$\begin{array}{c}\text { Clarity of } \\
\text { presentation }\end{array}$} & \multicolumn{2}{|c|}{ Applicability } & \multicolumn{2}{|c|}{$\begin{array}{c}\text { Editorial } \\
\text { independence }\end{array}$} \\
\hline & Agree & Con & Agree & Con & Agree & Con & Agree & Con & Agree & Con & Agree & Con \\
\hline \multicolumn{13}{|c|}{ Guidelines at primary level of prevention } \\
\hline 1. Canadian standard & 89 & 94 & 77 & 77 & 24 & 23 & 91 & 94 & 82 & 89 & 3 & 0 \\
\hline 2. CA Ontario guide & 85 & 89 & 20 & 17 & 10 & 8 & 70 & 72 & 61 & 67 & 0 & 0 \\
\hline 3. AU Prevent & 80 & 67 & 98 & 96 & 57 & 48 & 91 & 89 & 42 & 33 & 38 & 0 \\
\hline 4. Nice UK & 87 & 100 & 100 & 100 & 94 & 90 & 85 & 83 & 39 & 33 & 33 & 50 \\
\hline 5. HSE UK & 98 & 100 & 61 & 100 & 69 & 73 & 89 & 89 & 71 & 71 & 0 & 0 \\
\hline 6. Karolinska Sweden & 93 & 89 & 50 & 50 & 47 & 75 & 85 & 83 & 94 & 96 & 50 & 50 \\
\hline 7. WHO prima & 69 & 67 & 46 & 36 & 17 & 17 & 65 & 50 & 64 & 54 & 0 & 0 \\
\hline 8. WHO policy & 91 & 78 & 32 & 44 & 14 & 13 & 83 & 89 & 75 & 79 & 0 & 0 \\
\hline Level of quality a/Average & High/87 & High/86 & MLow/61 & Mod/65 & Poor/42 & Poor/43 & High/82 & High/81 & Mod/66 & Mod/65 & Poor/16 & Poor/13 \\
\hline \multicolumn{13}{|c|}{ Guidelines at tertiary level of prevention } \\
\hline 9. CA Montreal & 89 & 100 & 91 & 100 & 64 & 73 & 96 & 100 & 49 & 78 & 17 & 50 \\
\hline 10. OHS CA BA & 100 & 100 & 96 & 100 & 74 & 75 & 90 & 89 & 46 & 42 & 0 & 0 \\
\hline 11. AU RTW & 70 & 78 & 100 & 100 & 64 & 62 & 85 & 94 & 38 & 43 & 3 & 0 \\
\hline Level of quality a/Average & High/86 & High/93 & High/96 & High/100 & Mod/67 & Mod/70 & High/93 & High/94 & Poor/44 & $\mathrm{ML} / 54$ & Poor/7 & Poor/17 \\
\hline \multicolumn{13}{|c|}{ Guidelines at multiple level of prevention } \\
\hline 12. CA Vancouver & 82 & 78 & 72 & 78 & 18 & 19 & 86 & 72 & 79 & 83 & 0 & 0 \\
\hline 13. NRCWE, DK & 91 & 94 & 22 & 22 & 70 & 63 & 78 & 72 & 15 & 25 & 6 & 0 \\
\hline 14. MHAU & 71 & 89 & 7 & 6 & 43 & 42 & 79 & 78 & 32 & 46 & 0 & 0 \\
\hline 15. Public Sector, AU & 78 & 78 & 46 & 44 & 25 & 34 & 72 & 83 & 15 & 0 & 0 & 0 \\
\hline 16. OSH NZ & 69 & 17 & 27 & 8 & 49 & 11 & 62 & 11 & 67 & 19 & 8 & 2 \\
\hline 17. European Commission & 94 & 100 & 17 & 17 & 6 & 4 & 56 & 44 & 22 & 21 & 0 & 0 \\
\hline Level of quality a/Average & High/81 & Mod/76 & Poor/32 & Poor/29 & Poor/35 & Poor/29 & Mod/72 & Mlow/60 & Poor/38 & Poor/32 & Poor/2 & Poor/1 \\
\hline
\end{tabular}

a Levels of quality defined in this study: High $\geq 80 \%$; Mod=moderate: $\leq 79 \%$ and $\geq 65 \%$; MLow=moderately low: $\leq 64 \%$ and $\geq 50 \%$; Poor $\leq 49 \%$

coworkers to ensure peer support or necessary mentoring. Stress management training to increase employee resilience was also recommended by one guideline.

Evidence of tertiary preventive interventions. The interventions were expected to improve retention and facilitate the RTW process by improving rehabilitation and reducing the length of sickness absence. Two guidelines sufficiently developed their recommendations on the best available evidence also considering the mixed evidence to support these effects (numbers 9 and 10). The recommendation that workplace should facilitate access to evidence-based treatments or counselling were supported by evidence showing that such interventions were effective in treating MHP (50). Recommendations with regards to RTW mainly focused on factors facilitating RTW (eg, coordination, multidisciplinary approach) $(13,51)$ and rehabilitation of MHP in the context of work (eg, social support) (52) and barriers in implementing RTW interventions (53). Although this was the best available evidence at the time, the guidelines were developed recent evidence contradicts the positive effects of coordinating RTW (54) and, therefore, this recommendation is no longer valid.
Guidelines combining primary, secondary, tertiary preventive interventions

Recommendations for employers and management. Six guidelines recommended interventions combining organizational and individual interventions at the primary, secondary and tertiary level (guideline numbers 12-17, table 4.). The content of the primary and tertiary interventions overlapped in content with the other guidelines (numbers 1-11), but stressed the importance of targeting a wide range of organizational (eg, risk management) and individual level factors (eg, employee resilience or competence training) to achieve the desired effects. To detect MHP early, one guideline (number 14) suggested routine screenings, another (number 15) recommended to train the first line manager to detect signs of MHP. Others (numbers 13, 14, and 17) also recommended that the employer was responsible for organizing procedures to ensure peer-support, mentoring, or forums that enabled sick-listed or employees at risk to talk to each other. One guideline (number 17) provided thorough recommendations on how the organization could consider person-job fit, by continuous skills-training and rotating work schedules in jobs where psychosocial risks cannot be eliminated (eg, police departments). Implementation 
of these interventions were expected to mainly prevent work-related MHP and related stigma, reduce costs and promote well-being and retention.

Evidence of a combined approach. Although combining multiple preventive interventions seemed sensible from a political and theoretical perspective (14), only one guideline based their recommendations on a systematic review (number 13) and the evidence supporting the recommendations generally lacked rigor and was highly selective. Most guidelines emphasized that staying at work had a positive effect on employee health without consideration of the context (eg, conflicts at work, bullying) and possibilities of adverse health effects. Although the literature supported the beneficial effect of stress management training or counselling (50), evidence does not support the suggested benefits of screening (55) and the effectiveness of managers detection of MHP early has not yet been evaluated in the context of work.

\section{The quality of guidelines}

The difference (from $0-100 \%$ ) between the average scaled quality assessment scores and the consensus scores of all the guidelines across domains were small and differences were not significant (Mann-Whitney U test, $\mathrm{P}<0.05$ ). However, the discussion of scores had revealed some differences in the reviewer's conceptions of the AGREE rating manual. Consequently, the consensus scores were more valid, and these were applied in this review instead of the standard AGREE scores.

The quality of the guidelines varied considerably a cross the domains (table 5). While the quality of scope and purpose was generally high (domain i) the editorial independence (domain vi) was generally poor. The quality of stakeholder involvement (domain ii) and rigor of development (domain iii) varied according to the different levels of preventions presenting more challenges for multiple preventive guidelines. Although the quality of the clarity of presentation (domain iv) was mostly high, the quality of applicability (domain v) varied considerably. The developmental quality (domain i, ii and iii) of the guidelines varied according to the level of prevention (primary, tertiary and combined).

\section{Quality of primary preventive guidelines}

The quality of domain i (scope and purpose) was generally high, but the quality of domain ii (stakeholder involvement) and iii (rigor of development) varied considerably (guideline numbers $1-8$, table 5). Although most had involved key stakeholders only three guidelines (numbers 1, 3, and 7) specified how they had assessed their views and preferences. The quality of domain iv (clarity of presentation) was generally high and some had provided frameworks (guideline numbers 1, 6-9, table 4) to clarify the intervening mechanisms, and others had evaluated their own methods (eg, HSE management standards: number 5.). Four of the guidelines had high quality with regards to domain $\mathrm{v}$ (applicability) (numbers 1, 2, 5, and 6, table 5). These guidelines addressed some of the barriers related to implementation, such as access to external resources for small companies with limited resources. The quality of domain vi (editorial independence) was poor as none of the guidelines had clarified how funding partners or competing interest had influenced the development of guidelines. Only two primary preventive guidelines from England (guideline numbers 4 and 5) met all the criteria for good developmental quality (AGREE II $\geq 65 \%$ on domains i, ii and iii).

\section{Quality of tertiary preventive guidelines}

The quality of the three guidelines was mainly high or moderate across domains i-iv, but mostly poor with regards to applicability and editorial independence (domain v-vi) (guidelines 9-11, table 5).

Two Canadian tertiary preventive guidelines (guideline number 9 and 10) met all the criteria for good developmental quality.

\section{Developmental quality of multiple preventive guidelines}

The quality of scope and purpose was mainly high or moderate, but the stakeholder involvement and rigor of development was generally poor (guidelines 12-17, table 5). The quality of clarity of presentation and applicability ranged from high to poor, whereas the quality of editorial independence was poor.

None of the multiple preventive guidelines met all the criteria for good developmental quality.

\section{Discussion}

This systematic review identified 17 guidelines recommending workplace interventions to prevent or manage MHP. The content, expected effects and reported evidence of the recommended interventions overlapped considerably across guidelines. Only four guidelines had developed recommendations that met the criteria for good quality (AGREE II score $\geq 65 \%$ on domains i, ii and iii). Two guidelines from the UK [guideline number 4 (33) and 5 (34)] recommended that employers implement risk management procedures and programs to increase MH literacy of all employees and increased managers' communication and relational competences to prevent work-related MHP. The recommendations were 
underpinned by best available theory and evidence and the limited evidence of the effectiveness of implementing the guidelines were acknowledged. Two Canadian guidelines recommended interventions for employers and employees to facilitate RTW and rehabilitate workers who had been sick-listed with MHP (guideline number 9 [38-39) and 10 (40)]. Although they also based their recommendations on best available theory and evidence and acknowledged the limited available evidence with regards to their effectiveness at the time they had developed the guidelines (54), recent evidence contradicted some of the recommended interventions and the evidence base of the guidelines is therefore no longer valid.

No guidelines focused exclusively on detecting or managing MHP early. Guidelines recommending interventions that combined primary, secondary and tertiary preventive interventions seemed sensible from a political and theoretical perspective (14), but none met the criteria for good quality and the evidence underpinning the recommendations were inadequate.

To our knowledge, the HSE management standards (34) and one of the two Canadian RTW guidelines (38) have not been identified in previous reviews. Menish et al (18) also reviewed the NICE UK guideline (33) with AGREE II ratings similar to ours. One of the Canadian RTW guidelines (40) was also identified in another review (20). By contrast to our AGREE II scores, the previous review had considerably lower scores on rigor of development and stakeholder involvement. For several reasons, we nevertheless found our AGREE II scores valid. The guideline was underpinned by evidence from a systematic review conducted in accordance with NICE's review procedure and had involved stakeholders in a systematic way. To improve validity we had evaluated our ratings by a consensus score in addition to a standardized AGREE II procedure. Consequently we found the guidelines to be of good developmental quality.

Few of the guidelines considered the limited documented effect of implementing complex workplace interventions to all organizational contexts. Most guidelines recommended interventions that were not feasible without substantial financial and human resources. Although interventions were recommended to all workplaces regardless of size, lack of resources was not considered as a crucial barrier for smaller enterprises.

None of the guidelines had included sufficient statements regarding the views of the funding body or declarations of competing interests (domain vi: editorial independence items 22-23, table 2). Most of the guidelines included in this review had been developed by political, organizational and healthcare organizations - and only some in corporation with research institutes. The poor developmental quality questioned many of the claimed economic and health-related gains achieved by implementing the recommended interventions. Greater transparency of the different incentives, including political interests driving the development of guidelines could greatly improve the validity of guidelines.

One limitation of this study was the use of AGREE II as an instrument to evaluate the quality of occupational guidelines. Although, we had weekly consensus meetings to facilitate interrater reliability, the scope and target groups of the guidelines were in some cases different from clinical guidelines and were difficult to transfer to complex interventions in occupational settings. For example, the guidelines were not designed for mental health professionals and therefore simplicity was often prioritized over scientific clarification or disclaimers. Also, the applicability of guidelines was generally poor, which mostly reflected the generic nature of recommendations including broad statements designed to be applied to any employee in any organizational context.

We did a thorough literature search identifying documents from all over the world, but the scope was limited to guidelines written in English, Danish, Swedish or Norwegian. Although guidelines of better quality or content have not been identified in previous literature (18-20), the majority of guidelines included in the study were from North America, Australia, New Zealand or Europe and our results were mainly generalizable to these countries.

\section{Concluding remarks}

Actors at the workplace need guidelines of better quality to help prevent, detect and manage work-related MHP. None of the 17 included guidelines met the criteria on all the specified domains of quality and transparency of potential conflicting interests and applicability needed improvement. We identified four guidelines that had developed recommendations with sufficient rigor to help employers to either prevent or manage MHP. However, recent evidence proved crucial elements of the recommendations of how to best manage the MHP invalid. Additionally, evidence from effectiveness studies was scarce and future studies need to evaluate whether employers achieve the health- and work-related gains from implementing the guidelines. We did not identify guidelines that focused exclusively on detecting MHP early. An approach combining interventions to prevent, detect and manage MHP seemed innovative, but the evidence base and rigor of recommendations needed improvement. 


\section{Acknowledgements}

We thank Elizabeth Bengtsen at NRCWE for undertaking the literature search. This work was supported by governmental funding: STAR Research Fund grant. The funding source did not participate in any parts of the study.

\section{Competing interests}

Mette Andersen Nexø co-authored one of the guidelines reviewed in this study. To minimize potential bias, Mette Andersen Nexø did not participate in the ratings of the quality assessment of this guideline.

\section{References}

1. Bodenheimer T, Chen E, Bennett HD. Confronting the growing burden of chronic disease: can the U.S. health care workforce do the job? Health Aff (Millwood) 2009 JanFeb;28(1):64-74. http://dx.doi.org/10.1377/hlthaff.28.1.64.

2. Murray JC, Lopez AD. The Global Burden of Disease: A comprehensive assesment of mortality and disability from diseases, injuries, and risk factors in 1990 and projected on to 2020. Boston; 1996. Global Burden of Disease and Injury Series, vol 1.

3. OECD. Sickness, Disability and Work: Breaking the Barriers: A Synthesis of Findings across OECD Countries. OECD publishing, Paris. 2010.

4. Sanderson K, Andrews G. Common mental disorders in the workforce: recent findings from descriptive and social epidemiology. Can J Psychiatry 2006 Feb;51(2):63-75. http://dx.doi.org/10.1177/070674370605100202.

5. Gjesdal S, Ringdal PR, Haug K, Maeland JG. Longterm sickness absence and disability pension with psychiatric diagnoses: a population-based cohort study. Nord J Psychiatry 2008;62(4):294-301. http://dx.doi. org/10.1080/08039480801984024.

6. Kessler RC, Demler O, Frank RG, Olfson M, Pincus HA, Walters EE et al. Prevalence and treatment of mental disorders, 1990 to 2003. N Engl J Med 2005 Jun;352(24):2515-23. http://dx.doi.org/10.1056/ NEJMsa043266.

7. OECD. Fit Mind Fit Job. From Evidence To Practice in Mental Health and Work. OECD publishing, Paris. 2015.

8. Harnois G, Gabriel P. World Health Organization and International Labour Organization. Mental health and work: Impact, issues and good practices. WHO and ILO publishing, Geneva. 2000.

9. Gordon RS Jr. An operational classification of disease prevention. Public Health Rep 1983 Mar-Apr;98(2):107-9.

10. Rogerson S, Meir R, Crowley-McHattan Z, McEwen
K, Pastoors R. A Randomized Controlled Pilot Trial Investigating the Impact of a Workplace Resilience Program During a Time of Significant Organizational Change. J Occup Environ Med 2016 Apr;58(4):329-34. http://dx.doi. org/10.1097/JOM.0000000000000677.

11. Haracz K, Roberts E. Workplace resilience interventions show some evidence of positive effects, particularly on mental health and wellbeing. Aust Occup Ther J 2016 Feb;63(1):57-8. http://dx.doi.org/10.1111/14401630.12277 .

12. Sidle SD. Workplace Stress Management Interventions: What Works Best? Acad Manage Perspect 2008;22(3):1112. http://dx.doi.org/10.5465/AMP.2008.34587999.

13. Nieuwenhuijsen K, Faber B, Verbeek JH, NeumeyerGromen A, Hees HL, Verhoeven AC et al. Interventions to improve return to work in depressed people. Cochrane Database Syst Rev 2014 Dec;3(12):CD006237.

14. LaMontagne AD, Martin A, Page KM, Reavley NJ, Noblet AJ, Milner AJ et al. Workplace mental health: developing an integrated intervention approach. BMC Psychiatry 2014 May;14:131. http://dx.doi.org/10.1186/1471-244X-14-131.

15. Wagner SL, Koehn C, White MI, Harder HG, Schultz IZ, Williams-Whitt $\mathrm{K}$ et al. Mental Health Interventions in the Workplace and Work Outcomes: A Best-Evidence Synthesis of Systematic Reviews. Int J Occup Environ Med 2016 Jan;7(1):1-14. http://dx.doi.org/10.15171/ijoem.2016.607.

16. Joyce S, Modini M, Christensen H, Mykletun A, Bryant $\mathrm{R}$, Mitchell PB et al. Workplace interventions for common mental disorders: a systematic meta-review. Psychol Med 2016 Mar;46(4):683-97. http://dx.doi.org/10.1017/ S0033291715002408.

17. Eccles MP, Grimshaw JM, Shekelle P, Schünemann HJ, Woolf S. Developing clinical practice guidelines: target audiences, identifying topics for guidelines, guideline group composition and functioning and conflicts of interest. Implement Sci 2012 Jul;7:60. http://dx.doi. org/10.1186/1748-5908-7-60.

18. Memish K, Martin A, Bartlett L, Dawkins S, Sanderson K. Workplace mental health: an international review of guidelines. Prev Med 2017 Aug;101:213-22. http://dx.doi. org/10.1016/j.ypmed.2017.03.017.

19. Joosen MC, Brouwers EP, van Beurden KM, Terluin B, Ruotsalainen JH, Woo JM et al. An international comparison of occupational health guidelines for the management of mental disorders and stress-related psychological symptoms. Occup Environ Med 2015 May;72(5):313-22. http://dx.doi.org/10.1136/oemed-2013-101626.

20. Dewa CS, Trojanowski L, Joosen MC, Bonato S. Employer Best Practice Guidelines for the Return to Work of Workers on Mental Disorder-Related Disability Leave: A Systematic Review. Can J Psychiatry 2016 Mar;61(3):176-85. http:// dx.doi.org/10.1177/0706743716632515.

21. Moher D, Liberati A, Tetzlaff J, Altman DG, PRISMA Group. Preferred reporting items for systematic reviews and meta-analyses: the PRISMA statement. J Clin Epidemiol 2009 Oct;62(10):1006-12. http://dx.doi.org/10.1016/j. 
jclinepi.2009.06.005.

22. The Adapte Collaboration. The ADAPTE process: Resource Toolkit for guideline adaption. Version 2.0. 2009. Available from: http://www.g-i.n.net.

23. Shekelle P, Woolf S, Grimshaw JM, Schünemann HJ, Eccles MP. Developing clinical practice guidelines: reviewing, reporting, and publishing guidelines; updating guidelines; and the emerging issues of enhancing guideline implementability and accounting for comorbid conditions in guideline development. Implement Sci 2012 Jul;7:62. http:// dx.doi.org/10.1186/1748-5908-7-62.

24. Appraisal of Guidelines for Research and Evaluation (AGREE II) manual. 2013. Available from: https://www.agreetrust.org/ wp-content/uploads/2013/10/AGREE-II-Users-Manualand-23-item-Instrument_2009_UPDATE_2013.pdf.

25. Brouwers MC, Kho ME, Browman GP, Burgers JS, Cluzeau F, Feder G et al.; AGREE Next Steps Consortium. The Global Rating Scale complements the AGREE II in advancing the quality of practice guidelines. J Clin Epidemiol 2012 May;65(5):526-34. http://dx.doi. org/10.1016/j.jclinepi.2011.10.008.

26. Brouwers MC, Makarski J, Kastner M, Hayden L, Bhattacharyya O; GUIDE-M Research Team. The Guideline Implementability Decision Excellence Model (GUIDE-M): a mixed methods approach to create an international resource to advance the practice guideline field. Implement Sci 2015 Mar;10:36. http://dx.doi.org/10.1186/s13012-0150225-1.

27. Gagliardi AR, Brouwers MC. Do guidelines offer implementation advice to target users? A systematic review of guideline applicability. BMJ Open 2015 Feb;5(2):e007047. http://dx.doi.org/10.1136/bmjopen-2014-007047.

28. Siering U, Eikermann M, Hausner E, Hoffmann-Eßer W, Neugebauer EA. Appraisal tools for clinical practice guidelines: a systematic review. PLoS One 2013 Dec;8(12):e82915. http://dx.doi.org/10.1371/journal. pone. 0082915 .

29. Mental Health Commission of Canada. Psychological health and safety in the workplace: Prevention, Promotion, and Guidance to Staged Implementation. Bureau de normalisation du Quebec; Toronto, Canada: 2013.Retrieved from: http://www.mentalhealthcommission.ca/English/nationalstandard.pdf.

30. Canadian Mental Health Association. Ontario. Workplace mental health promotion: A How-To Guide. Ontario and Dalla Lana School of public health, University of Toronto; Publication year not stated. Retrieved from: http://wmhp. cmhaontario.ca/wordpress/wp-content/uploads/2010/03/ WMHP-Guide-Final1.pdf.

31. Reavley N. Workplace prevention of mental health problems: Guidelines for organisations. Melbourne School of Population and Global Health, University of Melbourne, Australia. 2013. Retrieved from: https://mhfa.com.au/sites/default/files/ GUIDELINES-for-workplace-prevention-of-mental-healthproblems.pdf.
32. Reavley NJ, Ross A, Killackey EJ, Jorm AF. Development of guidelines to assist organisations to support employees returning to work after an episode of anxiety, depression or a related disorder: a Delphi consensus study with Australian professionals and consumers. BMC Psychiatry 2012 Sep;12:135. http://dx.doi.org/10.1186/1471-244X-12-135.

33. National Institute for Health and Care Excellence. Mental wellbeing at work. Public Health Guideline. Manchester, UK. 2009. Retrieved from: https://www.nice. org.uk/guidance/ph22/resources/mental-wellbeing-at-workpdf-1996233648325.

34. Health and Safety Executive. How to tackle stress. A guide for employers on making the Management Standards Work. Suffolk, UK: Publication year not stated. Retrieved from: http://www.hse.gov.uk/pubns/indg430.pdf.

35. Riktlinjegruppen. Riktlinjer för psykisk ohälsa på arbetsplatsen [Guidelines for psychological ill health at the workplace] Sweden: Karolinska Institutet, Sveriges företags hälsor; 2015. Retrieved from: http://ki.se/sites/default/files/riktlinjer psykisk_ohalsa_utg_1_1_0.pdf.

36. Leka S, Cox T. PRIMA-EF: Guidance on the European framework for psychosocial risk management. A resource for employers and worker representatives. Protecting workers' health series, 9. World Health's Organization. 2008. Retrieved from: http://www.who.int/occupational_health/publications/ PRIMA-EF\%20Guidance_9.pdf.

37. World Health Organization. Mental health policies and progammes in the workplace. Mental health and Service Guidance Package. 2005. Retrieved from: http://www. who.int/mental_health/policy/services/13_policies $\% 20$ programs $\% 20$ in $\% 20$ workplace_WEB_07.pdf?ua $=1$.

38. St-Arnaud L, Corbiere M, Durand M, Bourbonnais R. Supporting a return to work after an absence for a mental health problem- design implementation, and evaluation of an integrated practices program. Quebeck, Canada: Universite Laval, Institut de recherche Robert-Sauve en sante et en securite du travail; 2014. Retrieved from: http://www.irsst. qc.ca/media/documents/PubIRSST/R-823.pdf.

39. St-Arnaud L. Pelletier. Guide to an integrated practices program for supporting a return to work and promoting job retention. Quebeck, Canada: Universite Laval, Institute de recherche Robert-Sauve en sante et en securite du travail; 2014. Retrieved from: http://www.irsst.qc.ca/media/ documents/PubIRSST/RG-813.pdf?v=2017-07-28.

40. Pomaki GF, Khushrushahi N, Murray E, Lampinen T, Mah P. Best practices for return to work/stay at work interventions for workers with mental health conditions. Vancouver: Occupational Health and Safety Agency for Healthcare in British Columbia; 2010. Retrieved from: http://www.ccohs. ca/products/webinars/best_practices_rtw.pdf.

41. Reavley N. Melbourne Uo. Helping employees sucessfully return to work following depression, anxiety or a related mental health problem- guidelines for organisations. Melbourne, Australia: Centre for Youth Mental health, University of Melbourne; 2011. Retrieved from: https://www. biomedcentral.com/content/supplementary/1471-244X-12- 
135-S1.pdf.

42. Center for Applied Research in Metnal Health and Addiction. Psychological health and safety. An action guide for employers. Ottowa: Mental Health Commission of Canada; 2012. Retrieved from: https://www.sfu.ca/content/dam/sfu/ carmha/resources/phsguide/Workforce_Employers_Guide_ ENG.pdf.

43. Borg V, Nexo MA, Kolte IV, Andersen MA. Hvidbog om mentalt helbred, sygefravær og tilbagevenden til arbejde[Whitepaper on mental health, sickness absence and return to work]. 2010. Retrieved from: http://www. arbejdsmiljoforskning.dk/ /media/Boeger-og-rapporter/ hvidbog-mentalt-helbred.pdf.

44. Harvey SB, Joyce S, Tan L, Nguyen H, Modini M, Groth M. Developing a mentally healthy workplace: A review of the literature A report for the National Mental Health Commission and the Mentally Healthy Workplace Alliance. Australia; 2014. Retrieved from: https://www.headsup.org.au/docs/ default-source/resources/developing-a-mentally-healthyworkplace_final-november-2014.pdf?sfvrsn=8.

45. Australian Government. As one- Working together: Promoting mental health and wellbeing at work. Australia; 2012. Retrieved from: http://www.comcare.gov.au/_data/ assets/pdf_file/0005/127454/working-together-mentalhealth-wellbeing-accessible.pdf.

46. Department of Labour. New Zealand. Healthy work. Managing Stress and fatigue in the workplace. Occupational Safety and Health Service, Department of Labour, Wellington, New Zealand. Retrieved from: http://www.worksafe.govt.nz/ worksafe/information-guidance/all-guidance-items/healthywork-managing-stress-and-fatigue-in-the-workplace/ stressfatigue.pdf.

47. Wynne R. V. DB, Leka S, Houtman I, McDaid D. Promoting mental health in the workplace: Guidance to implementing a comprehensive approach. 2014. Retrieved from: http:/www. ec.europa.eu/social $/$ main.jsp?catId=716\&langID=en.
48. LaMontagne AD. Invited commentary: job strain and health behaviors--developing a bigger picture. Am J Epidemiol 2012 Dec;176(12):1090-4. http://dx.doi.org/10.1093/aje/ kws337.

49. Hanisch SE, Twomey CD, Szeto AC, Birner UW, Nowak $\mathrm{D}$, Sabariego C. The effectiveness of interventions targeting the stigma of mental illness at the workplace: a systematic review. BMC Psychiatry 2016 Jan;6(16):1. http://dx.doi. org/10.1186/s12888-015-0706-4.

50. Richardson KM, Rothstein HR. Effects of occupational stress management intervention programs: a meta-analysis. J Occup Health Psychol 2008 Jan;13(1):69-93. http://dx.doi. org/10.1037/1076-8998.13.1.69.

51. Arends I, Bruinvels DJ, Rebergen DS, Nieuwenhuijsen K, Madan I, Neumeyer-Gromen A et al. Interventions to facilitate return to work in adults with adjustment disorders. Cochrane Database Syst Rev 2012 Dec;12(12):CD006389.

52. Brouwer S, Reneman MF, Bültmann U, van der Klink JJ, Groothoff JW. A prospective study of return to work across health conditions: perceived work attitude, self-efficacy and perceived social support. J Occup Rehabil 2010 Mar;20(1):104-12. http://dx.doi.org/10.1007/s10926-0099214-z.

53. Blank L, Peters J, Pickvance S, Wilford J, Macdonald E. A systematic review of the factors which predict return to work for people suffering episodes of poor mental health. J Occup Rehabil 2008 Mar;18(1):27-34. http://dx.doi.org/10.1007/ s10926-008-9121-8.

54. Vogel N, Schandelmaier S, Zumbrunn T, Ebrahim S, de Boer WE, Busse JW et al. Return-to-work coordination programmes for improving return to work in workers on sick leave. Cochrane Database Syst Rev 2017 Mar;3(3):CD011618.

55. Gilbody S, Sheldon T, House A. Screening and casefinding instruments for depression: a meta-analysis. CMAJ 2008 Apr;178(8):997-1003. http://dx.doi.org/10.1503/ cmaj.070281.

Received from publication: 8 September 2017 